\title{
Land Use/Land Cover Change Analysis using Markov-Based Model for Eleyele Reservoir
}

\section{BELLO, HO; *OJO, OI; GBADEGESIN, AS}

\author{
Ladoke Akintola University of Technology, Ogbomoso, Nigeria \\ *Corresponding AuthorEmail: oiojo@lautech.edu.ng
}

\begin{abstract}
Land Use and Land Cover (LULC) are important components of the environmental system and changes in it mirror the impacts of human activities on the environment. These impacts needed to be determined in order to get a clear picture of the extent at which different land use practices affect hydrologic regime and water quality. Therefore, this study analyzed the effects of LULC on Eleyele reservoir for a period of 32 years. Landsat images of 1984, 2000 and 2016 covered by path 191 and rows 55 were acquired, a modified version of Aderson scheme of LULC classification was used to stratify the images, while the LULC map was analyzed and projected until year 2032 using IDRISI Selva 17.0 and ERDAS 2013 softwares respectively. Changes that have occurred within the study area were determined using LULC MARKOV. Land Use Land Cover built up area increased from 688.30 ha to 952.68 ha and from 952.68 ha to 2164.5 ha between years 1984 to 2000, and 2000 to 2016 respectively. LULC maps of 2000 and 2016 showed the open water also reduced from 101.6 ha in year 2000 to 61.74 ha in 2016. DEM showed that $8.5 \%$, and $1.9 \%$ transitioned to vegetation cover and built up area in 1984 and 2000 respectively. Land Use Land Cover MARKOV chain analysis shows that by projection, the reservoir area will reduce further to 39.08 ha by the year 2032. The study has established that reserved forest zone suffered degradation with a noticeable increase in encroachment on the reservoir. LULC approach can be used to predict the effect of land use on reservoirs.
\end{abstract}

\section{DOI: https://dx.doi.org/10.4314/jasem.v22i12.8}

Copyright: Copyright (C) 2018 Bello et al. This is an open access article distributed under the Creative Commons Attribution License (CCL), which permits unrestricted use, distribution, and reproduction in any medium, provided the original work is properly cited.

Dates: Received: 26 June 2018; Revised: 21 November 2018; Accepted 18 December 2018

Keywords: land use; land cover; analysis; model; Eleyele; reservoir

Land use is the intended employment of land management strategy placed on the land cover by human agents, or land managers to exploit the land cover and reflects human activities such as industrial zones, residential zones, agricultural fields, grazing, logging, and mining among many others (Zubair, 2006; Chrysoulakis et al., 2004). According to Quentin et al., (2006) land use change is defined to be any physical, biological or chemical change attributable to management, which may include conversion of grazing to cropping, change in fertilizer use, drainage improvements, installation and use of irrigation, plantations, building farm dams, pollution and land degradation, vegetation removal, changed fire regime, spread of weeds and exotic species, and conversion to non-agricultural uses. Land use and land cover changes may be grouped into two broad categories as conversion and modification. Conversion refers to changes from one cover or use type to another, while modification involves maintenance of the broad cover or use type in the face of changes in its attributes (Baulies and Szejwach, 1998). It is estimated that undisturbed (or wilderness) areas represent $46 \%$ of the earth's land surface. Forests covered about $50 \%$ of the earth's land area 8000 years ago, as opposed to $30 \%$ today as agriculture has expanded into forests, savannas, and steppes in all parts of the world to meet the demand for food and fiber (Lambin et al., 2003). Based on data from diverse sources, the Global Forest Resources Assessment 2000 estimated that the world's natural forests decreased by 16.1 million hectares per year on average during the 1990s, which is a loss of $4.2 \%$ of the natural forest that existed in 1990 (Lambin et al., 2003). Land use in East Africa has changed swiftly over the last half-century: expansion of mixed crop-livestock systems into former grazing land and other natural areas and intensification of agriculture are the two largest changes that have been detected (Olson and Maitima, 2006). Accordingly, land cover classification has recently been a hot research topic for a variety of applications (Liang et al., 2002). A great deal of research has been conducted throughout the world in an attempt to understand major shifts in land use and land cover and to relate them to changing environmental conditions. Therefore, Land use and land cover change (LULC) research needs to deal with the identification, qualitative description and parameterization of factors, which drive changes in land use and land cover, as well as the integration of 
their consequences and feedbacks (Baulies and Szejwach, 1998). However, one of the major challenges in LULC analysis is to link behavior of people to biophysical information in the appropriate spatial and temporal scales (Codjoe, 2007). Nevertheless, it is argued that land use and land cover change trends can be easily accessed and linked to population data, if the unit of analysis is the national, regional, district or municipal level. LUCC studies have been designed to improve understanding of the human and biophysical forces that shape land use and land cover change. Land use and land cover plays an important role in global environmental change and sustainability, including response to climate change, effects on ecosystem structure and function, species and genetic diversity, water and energy balance, and agro-ecological potential. Land use and land cover mapping is one of the most important and typical applications of remote sensing data (Chrysoulakis et al., 2004). Remotely sensed data are a useful tool, have scientific value for the study of human environment interactions, especially land use, and land cover changes (Dale et al., 1993; Codjoe, 2007). Remote sensing change detection techniques can be broadly classified as either pre- or post-classification change methods. A pre-classification process refers to operations carried out to bring satellite images to the desirable geometric and spectral standard by correcting errors, and it is performed prior to image classification. Research evaluating the comparative performance of various land cover change detection methods has indicated that no uniform combination of data types and methods can be applied with equal success across different ecosystems (Lu et al., 2004; Lunetta et al., 2006). The study assessed the impact of land use on Eleyele Water Reservoir, and evaluated the relationship between the reservoir and the weather parameters.

\section{MATERIALS AND METHODS}

The Study Area: Eleyele Lake Forest is located in Ibadan North West Local Government Area of Oyo State, Nigeria. The forest lies within latitude $7^{0} 30^{\prime}-$ $7^{0} 45^{\prime} \mathrm{N}$ and longitude $3^{0} 55^{\prime}-3^{0} 88^{\prime} \mathrm{E}$. The study area is surrounded by Eleyele neighborhood in the south, Apete in the east and Awotan in the north. Eleyele wetland is a modified natural riverine wetland type with area of about $100 \mathrm{Km}^{2}$ including the catchment area. The elevation is relatively low ranging between 100-150 m above sea level and surrounded by quartzridge hills toward the downstream section where the Eleyele dam barrage is located. The total area of the reserve is 526.0921 hectares and was originally acquired by government under the public lands acquisition ordinance in 1941 (Akingbogun, et al., 2012), the reservoir was made by damming River Ona.
Figure 1 shows the Map of Ibadan showing the location of Eleyele Reservoir while Figure 2 showing the Topography Map of the Study Area.

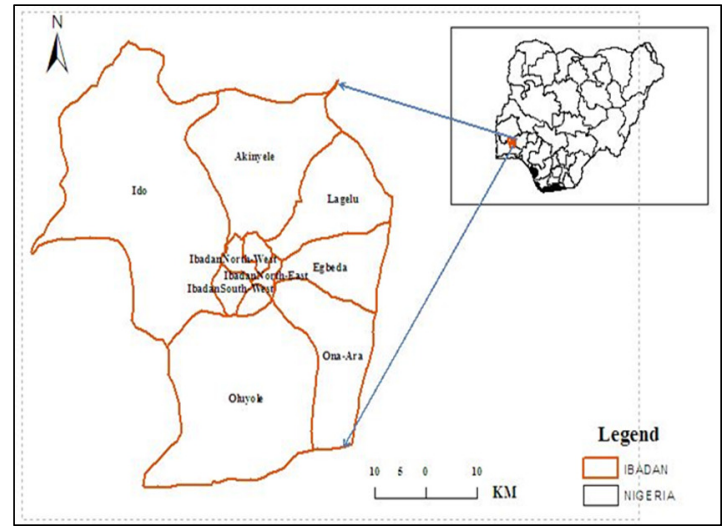

Fig 1: Map of Ibadan showing the location of Eleyele Dam (Source: FRIN, 2016)

Methods: This research study employed GIS and Remote Sensing techniques. The general procedure used in this study is as stated. Several data sets are prepared as inputs to the ArcGIS and IDRISI software. Model setup includes drainage basin delineation in Global Mapper model interface using SRTM image while the DEM (Digital Elevation Model) was developed in Suffer software environment. The LULC maps were produced from Satellite images of 1984, 2000 and 2016, the analyses were carried out in ArcMap and IDRISI software environments.

Data acquisition: The following data were acquired for use: 1. Landsat images of 1984, 2000 and 2014 for land use/cover mapping; 2. Shuttle Radar Topography Mission (SRTM) image for DEM, slope and aspect, and drainage pattern generation. 3. Quick Bird/ Google Earth images for the delineation of the study area. 3. Weather parameters.

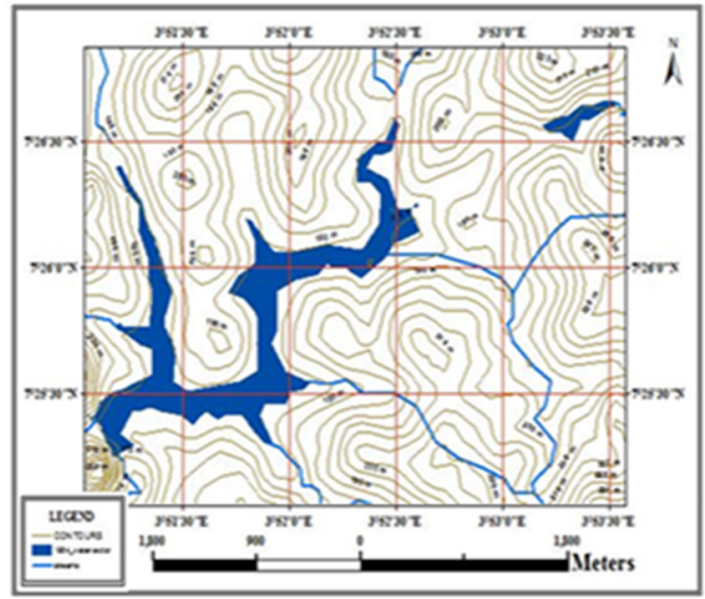

Fig 2: The topography map of the study area 
Data preparation: Land Use/Cover Map of Eleyele basin was generated using Landsat 7TM and eight ETM+ images covered by path 191 , rows 55, these satellite images were obtained as rectified data, and a supervised classifier (parallelepiped classification) was used to stratify the images. The land cover map was analysed and projected using IDRISI Selva 17.0 and ERDAS 2013 software (Agbor et al., 2012). The land use/cover classes considered were Forestland, built-up area and water body.

Spectral Respond Pattern: The steps involved in processing the satellite images include developing a spectral respond pattern for easy identification of features in the images Spectral respond pattern is useful in identifying what the remotely sensed images "mean" (IDRISI Manual 17.0). Types identified in the image were built-up, land-cover up, vegetation cover and water area. To explore how these different cover types reflect, each of the electromagnetic wavelengths recorded in the original bands of imagery, reflectance values in all seven images were extracted. In addition, a simultaneous query of all the images grouped in a raster image file as recommended by Ojo (2013) as shown in Figure 3, classified as open water, vegetation, and built up.

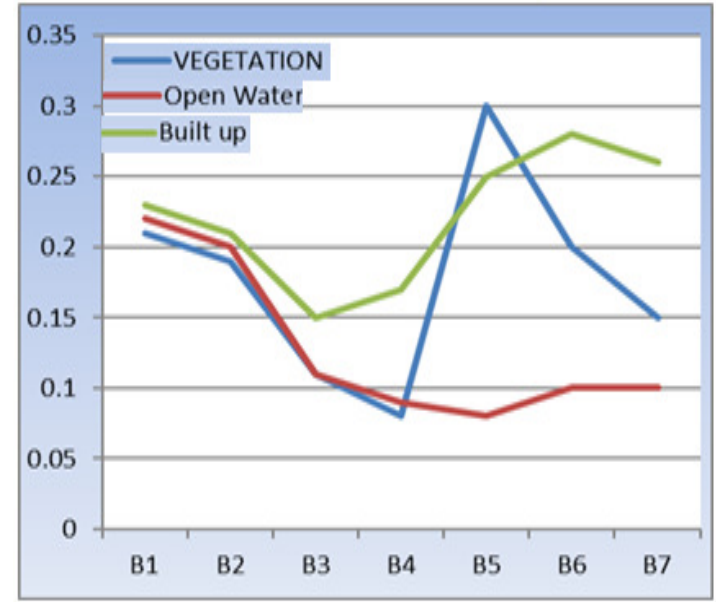

Fig 3: Spectral Respond Pattern (Ojo, 2013)

Mapping the land use land cover types and changes: Land use and land cover patterns for 1989, 1998 and 2015 have been mapped by the use of Landsat TM, ETM and OLI data (path and row: 191 and 55), which have a $30-\mathrm{m}$ ground resolution with the exception for the thermal IR bands (band 6) and (10-11) respectively, which have $100-\mathrm{m}$ resolution bands. A modified version of the Anderson scheme of land use/cover classification has been adopted and the categories include (1) Bare land, (2) Vegetation and (3) Water body.
Image preprocessing: In raw remote sensing data, each pixel has digital number value that corresponds to a raw measurement required by the sensor (Giannini et al, 2015). To obtain quantitative information from images, digital number must be converted to physical quantities, radiance and brightness temperature, it is necessary to correct the previously calibrated images by atmospheric effects. The presence of the atmosphere can cause significant distortions in the radiometric signal. The images used in this study were first converted to Top of atmosphere (TOA) radiance using Equation 1 (Giannini et al, 2015).

$$
L \lambda=\left(\frac{\left(L_{M A X} \lambda-L_{M I N} \lambda\right)}{Q_{C A L} \lambda}\right) Q_{C A L}+L_{M I N} \lambda \quad \mathbf{1}
$$

Where: $L \lambda=$ Spectral radiance at the sensor's aperture $\left[\mathrm{W} /\left(\mathrm{m}^{2} \mathrm{sr} \mu \mathrm{m}\right)\right] ; \mathrm{Q}_{\mathrm{CAL}}=$ Quantized calibrated pixel value $[\mathrm{DN}] ; \mathrm{Q}_{\mathrm{CAL}} \mathrm{MIN}=$ Minimum quantized calibrated pixel value corresponding to $\mathrm{L}_{\mathrm{MIN}}[\mathrm{DN}]$; $\mathrm{Q}_{\mathrm{CAL}} \mathrm{MAX}=$ Maximum quantized calibrated pixel value corresponding to $\mathrm{L}_{\mathrm{MAX}}$ ) [DN]; $\mathrm{L}_{\mathrm{MIN}}=$ Spectral at-sensor radiance that is scaled to $\mathrm{Q}_{\mathrm{CAL}} \mathrm{MIN}$ [W/ $\left.\left(\mathrm{m}^{2} \mathrm{sr} \mu \mathrm{m}\right)\right] ; \mathrm{L}_{\mathrm{MAX}},=$ Spectral at-sensor radiance that is scaled to Qcal $_{\max }\left[\mathrm{W} /\left(\mathrm{m}^{2} \mathrm{sr} \mu \mathrm{m}\right)\right]$.

Since equation 1 does not consider the atmospheric effects, there is therefore the need to incorporate images atmospheric correction from radiance to reflectance measures using equation 2 (Gyanesh et al., 2009).

$\rho \lambda=\frac{\pi \cdot T O A r \cdot d^{2}}{E_{S U N} \lambda \cdot \operatorname{Cos} \theta_{S Z}}$ 2

Where: $\rho \lambda=$ Planetary TOA reflectance (unitless); $\pi=$ mathematical constant approximately equal to 3.14159 (unitless); $L \lambda=$ Spectral radiance at the sensors aperture $\left[\mathrm{w} /\left(\mathrm{m}^{2} \mathrm{sr} \mu \mathrm{m}\right)\right] ; d^{2}=$ The earth-Sun distance (Astronomical unit); $E_{S U N}=$ Meanexo atmospheric solar irradiance $\left[\mathrm{w} /\left(\mathrm{m}^{2} \mathrm{sr} \mu \mathrm{m}\right)\right] ; \theta_{\mathrm{sz}}=$ the solar zenith angle (degree). The cosine of this angle is equal to the sine of the sun elevation $\theta_{\mathrm{SE}}$. Therefore, $\theta_{\mathrm{SZ}}=90-\theta_{\mathrm{SE}}$.

These are rescaling factors given in metadata.

Image classification algorithm: The images were classified using a supervised classification algorithm called Bayclass classifier, which is one of a group of soft classifiers in IDRISI software system. Unlike hard classifiers, soft classifiers defer making a definitive judgment about the class membership of any pixel in favour of producing a group of statements about the degree of membership of that pixel in each of the possible classes. Like traditional supervised 
classification procedures, each uses training site information for classifying each image pixel. However, traditional hard classifiers output is not a single classified land cover map, but rather, a set of images (one per class) that expresses for each pixel the probability that it belongs to each class (Giannini et al, 2015).

LULC change analysis using Markov-Based Model: A raster data model in GIS (Markov-based) were used to represent continuous data over space. The model will divide the area into grid cells or pixels where each grid cell were filled with the measured attribute values in a matrix and cell values were written in rows and columns. CA-Markov models represent, for example, a forest area with lattice of cells, each of which exists in one of a finite set of states.

The progression of time were modeled as a series of discrete steps with future patterns determined by transition rules, which specify the behavior of cells over time, for example, a cell switches from forest area to built-up area, as a function of conditions at each cell and its neighboring cells at each time step (Giannini et $a l, 2015)$. The pixel value of the raster data model in classified images and the simulated images from CAMarkov represents each land using land use and cover change data derived from satellite images. This study also established the validity of the Markov process for describing and projecting land use and cover changes in the study area by examining statistical independence, Markovian compatibility, and the states of the data as the Markov chain has $n$ states. The data vector is a column vector whose ith component represents the probability that the system is in the ith state at that time. It is important to note that the sum of the entries of a state vector is 1 ; vectors $X_{0}$ and $X_{1}$ in the above example are state vectors. If pij is the probability of movement (transition) from one state $\mathrm{j}$ to state $i$, then the equation 3 is called the transition matrix of the Markov chain (Kampanart et al., 2016).

$$
\mathrm{T}=[\mathrm{pij}]
$$

The CA-Markov analysis was used to test run a pair of land cover images and outputs a transition probability matrix and a transition areas matrix. The transition probability matrix explain the probability that each land cover category changed to every other category. The transition areas matrix is the number of pixels that are expected to change from each land cover type to every other land cover type over the specified number of time units. Based on this a four-state markov probability matrix has been developed (Takayama et al., 1997).
Data Analysis: The analysis of data were carried out using IDRISI, landsat image Google Earth and shuttle radar topography mission (SRTM) softwares. Changes that have occurred within then study area were determined using a land use and land cover change procedure called CA_MARKOV chain analysis. This helped in correlating changes GPS for navigation and recording of coordinates of landmark features.

\section{RESULTS AND DISCUSSION}

The results are presented inform of images/maps, graphs and statistical tables which include the land cover types, change maps and land use land cover transition maps and land use land cover types over the study years.

Land Use Land Cover (LULC) Pattern in the study area: A supervised (full Gaussian) maximum likelihood classification was implemented for the three images and the final classification products provide an overview of the major land use / land cover features of the study area for the years, 1984, 2000 and 2016. Three categories of land use / land cover were identified as built up area, vegetation and water body. Figures 4, 5, and 6 illustrate the land use / land cover map for the years considered. The LULC maps showed change pattern and the changes were quite drastic between 2000 and 2016.

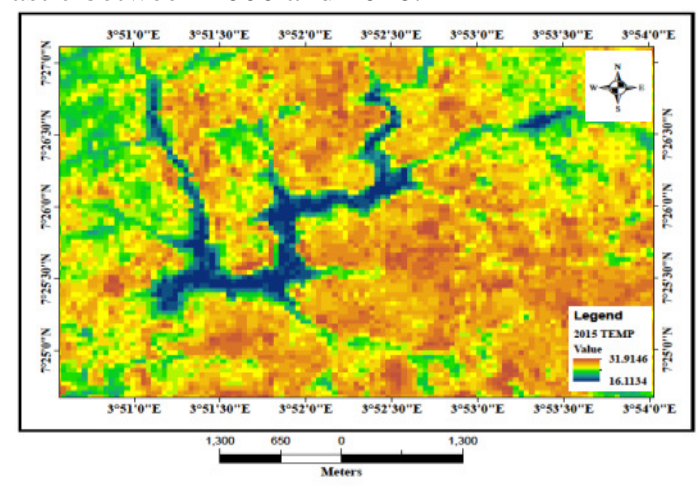

Fig 4: 1984 Land Use Land Cover

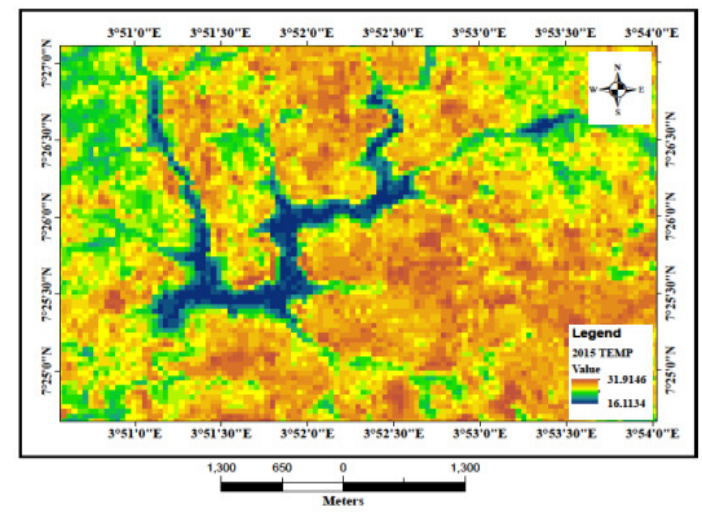

Fig 5: 2000 Land Use Land Cover 


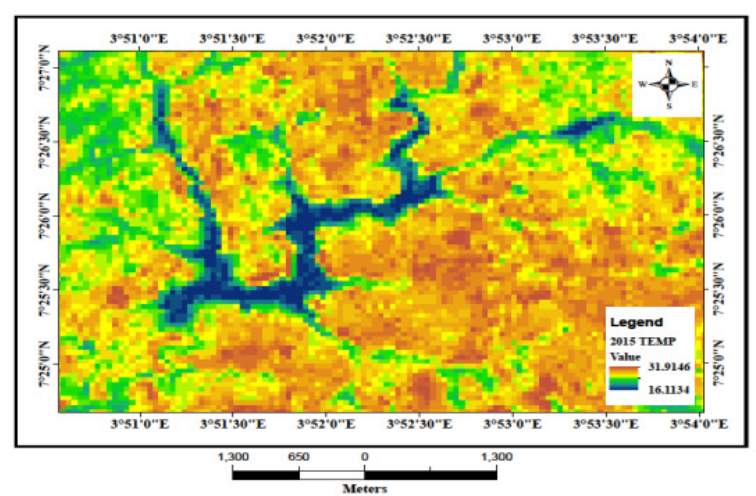

Fig 6:2016 Land Use Land Cover

The statistics of LULC in 1984, 2000, 2016 and 2032 were stated in Tables 1 and 2 . In order to obtain the area extent (in hectares) of the resulting land use / land cover type for each study year and for subsequent comparison. Tables 1 and 2 showed the spatial extent of land cover in hectares and in percentages, while Figure 7 showed a dramatic increase in built area between 2000 and 2016, it also indicates that both water body and vegetation cover continued to decrease. These results conformed to the study on land use and land cover changes effects on human environment interactions by Codjoe (2007).

Table 1: Land use Land Cover distribution pattern between 1984 and 2016

\begin{tabular}{|c|c|c|c|}
\hline Category & 1984 & 2000 & 2016 \\
\hline & Hectare $\%$ & Hectare $\%$ & Hectare $\%$ \\
\hline Built Up Area & $688.30065 \quad 17.61$ & 1952.68802524 .47 & 2164.5 \\
\hline Open Water & 122.7390753 .14 & $101.55255 \quad 2.59$ & $61.74 \quad 1.58$ \\
\hline \multicolumn{4}{|c|}{ Vegetation Cover 3097.84027 .79 .2528}$. \\
\hline TOTAL & 3908.88 & 3908.88 & 3908.88 \\
\hline
\end{tabular}

\begin{tabular}{llll}
\multicolumn{3}{c}{ Table 2: 2032 LULC } \\
\hline Category & $\mathbf{2 0 3 2}$ & & \multicolumn{1}{c}{ Legend } \\
\cline { 2 - 3 } $\mathbf{1}$ & Hectares & \% & \\
$\mathbf{2}$ & 2289.42 & 58.00 & Built Up Area \\
$\mathbf{3}$ & 54.54 & 1.39 & Open Water \\
TOTAL & 1564.92 & 40.03 & Vegetation Cover \\
\hline
\end{tabular}

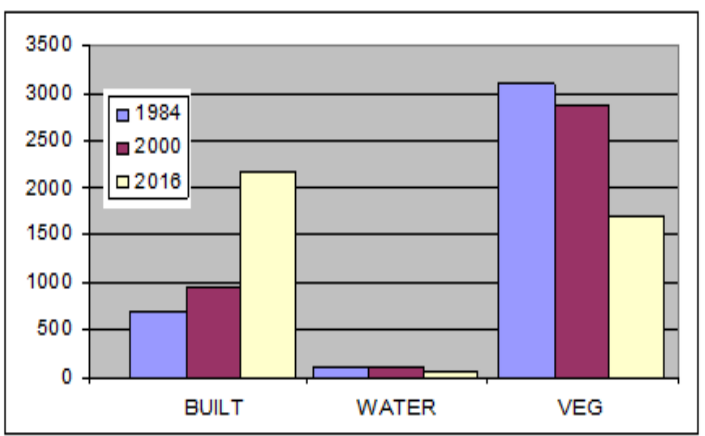

Fig 7: Land cover types over the years (1984-2016) in Hectare

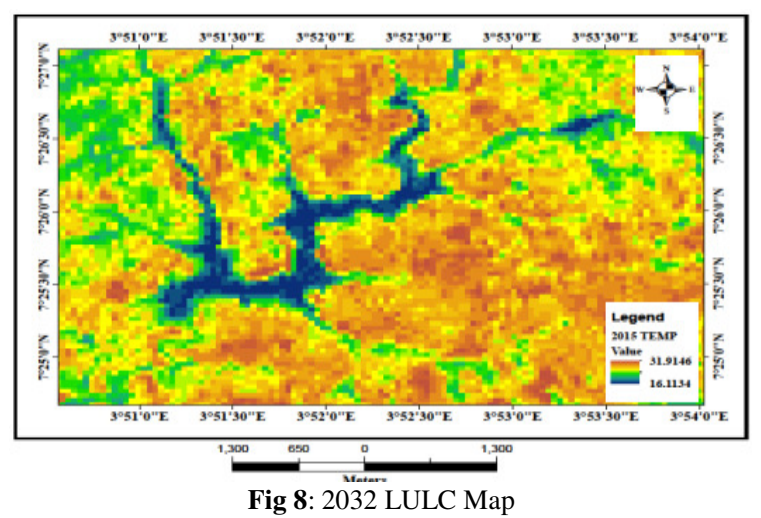

Land Use land Cover Projection using Markov Operation: Markov chain analysis described land use change from one period to another and used to project future change. From Table 4, it is clear that the water body / class is endangered because of the high probability of it transitioning into built up area, the area extent of the vegetation cover is likely to be taken over by the built up area between 2000 and 2016 . These probabilities show serious threat faced by Eleyele both now and the nearest future due to anthropogenic activities. The decrease in open water from $2.59 \%$ to $1.58 \%$ is a reflection of the given statistics in Table 5.

Table 4: Markov: 2000/2016 Transition Probability of LULC changes

\begin{tabular}{llll}
\hline LULC & $\begin{array}{l}\text { Built } \\
\text { Up }\end{array}$ & $\begin{array}{l}\text { Open } \\
\text { Water }\end{array}$ & $\begin{array}{l}\text { Vegetation } \\
\text { Cover }\end{array}$ \\
\hline Built Up & 0.6294 & 0.0116 & 0.3589 \\
Open Water & 0.5794 & 0.0472 & 0.3734 \\
Vegetation Cover & 0.5277 & 0.0158 & 0.4565 \\
\hline
\end{tabular}

Table 5: 2032 Transition Table

\begin{tabular}{lcll}
\hline Category & $\mathbf{2 0 3 2}$ & & Legend \\
\hline & Hectares & $\%$ & \\
\hline $\mathbf{1}$ & 2289.42 & 58.00 & Built Up Area \\
$\mathbf{2}$ & 54.54 & 1.39 & Open Water \\
$\mathbf{3}$ & 1564.92 & 40.03 & Vegetation Cover \\
TOTAL & 3908.88 & & \\
\hline
\end{tabular}

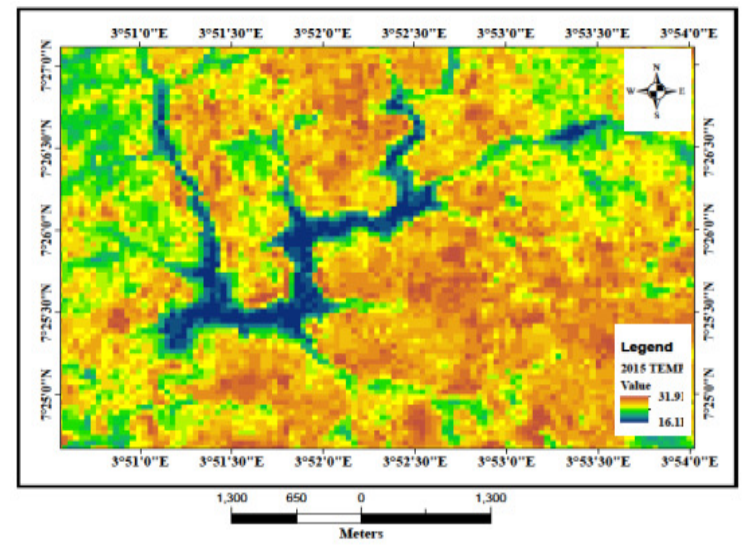

Fig 9: 2000/2016 Change Map 
Transition mapping: The change map (Figure 9) shows how land cover types transitioned to other types between 1984 and 2000. For example, 8.5\% of vegetation in 1984 transitioned to built-up area in 2000 , while $1.9 \%$ of built up area transitioned to vegetation area denoting change statistics shown in Table 6.

Table 6: Change map statistics

\begin{tabular}{llll}
\hline Category & Hectares & \% & Legend \\
\hline $\mathbf{1}$ & 330.9918750 & 8.47 & $\begin{array}{l}\text { vegetation cover } \\
\text { to built up area } \\
\text { vegetation cover } \\
\text { to open water } \\
\text { built up area to } \\
\text { vegetation cover } \\
\text { open water to } \\
\text { vegetation cover }\end{array}$ \\
$\mathbf{4}$ & 18.9254250 & 0.48 & 1.96 \\
\hline
\end{tabular}

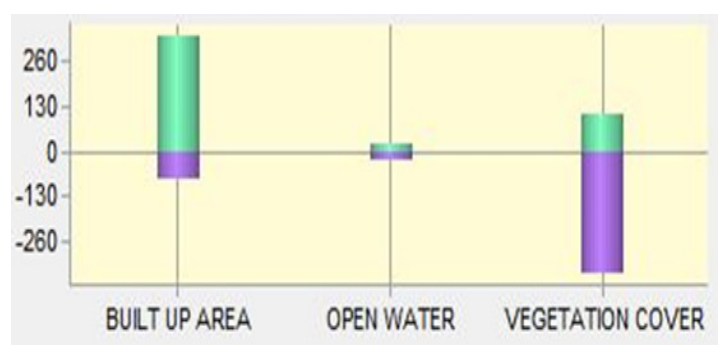

Fig 10: Gains and Losses of land use land cover type between 1984 and 2000

The gains and losses graph (Figure 10) reveals the drastic decrease in vegetation cover and large increase in built up area, between 1984 and 2000. The gains and losses of the land cover types between 1984 and 2000 are shown in Figure 10, with vegetation losing more to other land types by about $8.5 \%$. The findings human activities as one of the major challenges in LU-LC analysis in the appropriate spatial and temporal scales (Codjoe, 2007, Ojo, 2013).

Table 7: Transitions for LULC

\begin{tabular}{cll}
\hline Category & Hectares & Legend \\
\hline $\mathbf{1}$ & 611.5430250 & $1 / 1$ \\
$\mathbf{3}$ & 330.9918750 & $3 / 1$ \\
$\mathbf{5}$ & 94.6271250 & $2 / 2$ \\
$\mathbf{6}$ & 18.9254250 & $3 / 2$ \\
$\mathbf{7}$ & 76.7576250 & $1 / 3$ \\
$\mathbf{8}$ & 28.4287500 & $2 / 3$ \\
$\mathbf{9}$ & 2747.9229750 & $3 / 3$ \\
\hline Note: & 1-built up area, 2-open water and 3-vegetation cover
\end{tabular}

Cross-Classification: Cross-classification performed using CROSSTAB module in IDRISI through analysis that compares images containing categorical variables of two types. For the first type used in this study, which is hard classification, all pixels in the maps have complete membership to exactly one category resulting into a cross-classification image and table as outputs. Olga et al., (2013) study in assessing spatial dynamics of urban growth using an integrated land use model agreed to the results in Table 7, Figures 11 and 12 depicting the built up area, open water and vegetation cover dynamics.

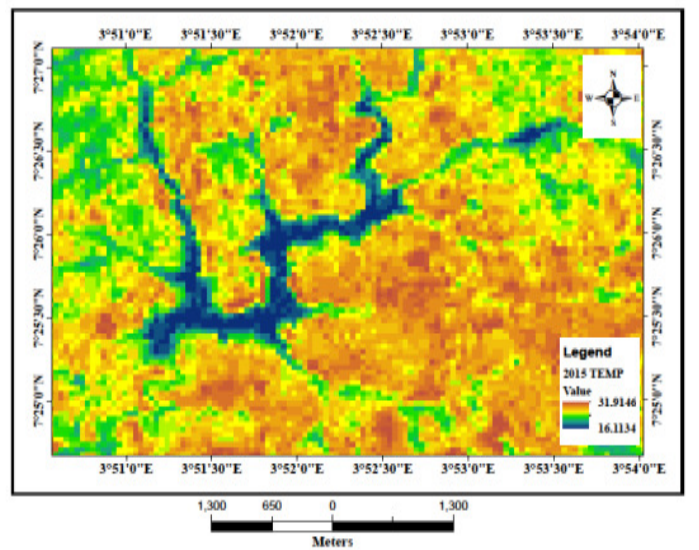

Fig 11: Image cross-classification between 1984 and 2000

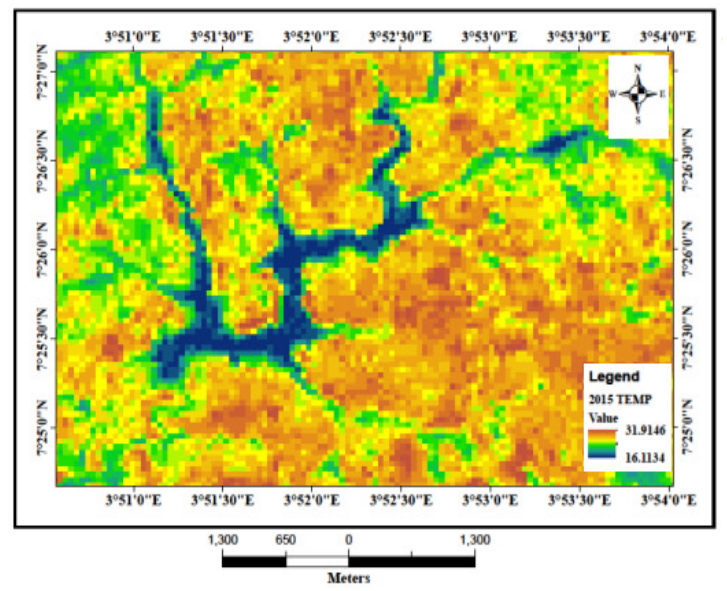

Fig 12: Image cross-classification between 2000 and 2016

Conclusion: The 1984, 2000 and 2016 Landsat TM/OLI satellite data were used to identify and classify LULC types of the study area as a GIS database of land use categories and their location within 32 years (1984-2016) was generated and analyzed with the aid of GIS analytical functions. The results showed that urban growth (anthropogenic factors) within the study area imposes a lot of pressure on the reservoir. Between 1984 and 2016, the depth of the reservoir reduced significantly. By considering the LULC maps of 2000 and 2016 shows how drastic the reservoir as decreased from 101.6 ha in 2000 to 61.74 ha in 2016 which amount to 39.08 ha. The reserved forest zone has suffered degradation seriously and if the similar trend continues, the encroachment will further reduce the reservoir area and the surrounding reserved forest will disappear. By projection, the reservoir area will reduce by $1 \%$ (39.08 ha) of the total area considered for the study area by the year 2032 . More image cross-sections should be used to derive 
more estimates, which can be averaged to determine a value that is most representative of the stream. Check mating the activities of man, which was observed in the course of the fieldwork to reduce forest degradation.

\section{REFERENCES}

Agbor C.F., Aigbokhan O.J., Osudiala C.S., and Malizu, L.L. and (2012). Land Use Landover Change Prediction of Ibadan Metropolis. J. Forestry Res. Manage. 9, 2012.

Akingbogun A.A., Oloyede, S.O.A. Kosoko and D.K. Aborisade (2012). Remote Sensing and GIS Application For Forest Reserve Degradation Prediction And Monitoring First FIG Young Surveyors Conference Knowing to create the Future Rome, Italy, 4-5 May 2012

Baulies, X., and Szejwach, G., (1998). LUCC data requirements workshop survey of needs, gaps and priorities on data for land-use/land-cover change research organized by IGBP/IHDP-LUCC AND IGBP-DIS, Barcelona, Spain, 11-14 November 1997 LUCC report series no. 3.

Chrysoulakis, N., Kamarianakis, Y., Farsari, Y., Diamandakis, M. and P. Prastacos (2004). Combining Satellite and Socioeconomic data for Land Use Models estimation. I

Codjoe, S.N.A. (2007). Integrating Remote Sensing, GIS, Census, and Socioeconomic Data in Studying the Population-Land Use/Cover Nexus in Ghana: A Literature Update. Africa Development, XXXII (2) 197-212.

Coles, T.E., Wells, S.A. (2003). CE-QUAL-W2: a two-dimensional laterally averaged, hydrodynamic and water quality model, Version 3.1. Instruction Report EL-03-1, U.S. Army Engineering and Research Development Center, Vicksburg, MS.

Dale, V. H., O’Neill, R. V., Pedlowski, M. and Southworth, F. (1993). 'Causes and Effects of Land Use Change in Central Rondonia, Brazil. Photogrametric Engineering and Remote Sensing, 59 (6) 997-1005.

Eric C. Barrett and Leonard F. Curtis (1999). Introduction to environmental remote Sensing

FAOSTAT, (2006). 2006 Database. Food and Agriculture Organization, Rome. Available at: http://faostat.fao.org/
Franczyk, J., and Chang, H. (2009). The effects of climate change and urbanization on the runoff of the rock creek basin in the Portland metropolitan area, Oregon, USA. Hydrological Processes, 23(6), 805-815. Doi: 10.1002/hyp.7176

Giannini, A.; Salack, S.; Lodoun, T.; Ali, A.; Gaye, A.T. and Ndiaye, O. (2013). A unifying view of climate change in the Sahel linking intra-seasonal, inter-annual and longer time scales. Environmental Research Letters 8 (2): 024010.

Giannini, V., A.A. Allan, C. Hutton, C. Giupponi, F.A. Johnson. (2015) IWRM responses to cope with "what if?" scenarios. IN: W.A. Flügel \& N. Sharma (Eds.). Applied Geo-informatics for Sustainable Integrated Water resources Management (IWRM). Results from the EU-project BRAHMATWINN. Springer ISBN: 978-81-322-1966-8.

Gyanesh, C., Brian, L. M., \& Dennis, L. H. (2009). Summary of current radiometric calibration coefficients for Landsat MSS, TM, ETM+, and EO-1 ALI sensors. Remote Sensing of Environment, 113, 893-903.

Kampanart Piyathamrongchai, Thanapong Thanutgit and Sittichai Choosumrong. (2016) Modelling Land Use Change using Cellular Automata Model: A Case Study of Wangthong City, Phitsanulok province, Thailand. International Conference on GeoInformatics for Spatial-Infrastructure Development in Earth \& Allied Sciences (GISIDEAS). Available online at gisws.media.osakacu.ac.jp/gisideas16/. ESASGD 2016. GIS-IDEAS.

Krishnamurthy J., Venkatesa K. N., Jayaraman V. and Manivel M. (1996). Approach to Demarcate ground water potential zones through remote sensing.

Lambin, E.F., Geist H.J., and lepers, E., (2003). Dynamics of land-use/land cover 1990-2014 Change in tropical regions, annual review of environmental Resources, 28:205-41.

Liang, S, Fang, H., Morisette, J.T, Chen, M., Shuey, C.J., Walthall C.L., Daughtry, C.S, (2002). Atmospheric Correction of Landsat ETM+ Land Surface Imagery: II. Validation an applications. IEEE Transactions on Geoscience and Remote Sensing,

Lin, W.E. and Pierce, F.J. (2009). The Dynamics of Soil Quality as a Measure of Sustainable Management. In (eds.) Doran, J.D., Coleman, 
D.C., Bezdicek, D. F., Lunetta, R.L., Knight, F.K, Ediriwickrema, J., Lyon, J.G., and Worthy, L.D., 2006. Land covers change detection using multitemporal MODIS NDVI data. Remote Sensing of Environment, 105, 142-154.

Lu, D., Mausel, P., Brondizio, E., and Moran, E. (2004). Change detection techniques. Int. J. Remote Sensing, 20(12), 2365-2407.

Lunetta, R.L., Knight, F.K, Ediriwickrem A, J., Lyon, J.G., and Worthy, L.D., (2006). Land cover change detection using multi-temporal MODIS NDVI data. Remote Sensing of Environment, 105, 142154.

Ojo, O. I. (2013). Mapping and modeling of irrigation induced salinity in Vaal Harts Irrigation scheme, South Africa: a DTech Thesis submitted to the Department of Civil Engineering, Tshwane University of Technology, Pretoria, South Africa.

Olga Lucia Puertas, Cristian Henríquez and Francisco Javier Meza. (2013). Assessing spatial dynamics of urban growth using an integrated land use model. Application in Santiago Metropolitan Area, 2010 2045. Land Use Policy, 38(2014), 415-425.
Olson, Jennifer M., Bilal Butt, Fred Atieno, Joseph Maitima, Thomas A. Smucker, Eric Muchugu, George Murimi, and Hong Xu. 2004. Multi-scale analysis of land use and management changes on the Eastern Slopes of Mt. Kenya. Nairobi: International Livestock Research Institute.

Quentin F. B., Jim, C., Julia, C., Carole, H., and Andrew, S., (2006). Drivers of land use change, Final report: Matching opportunities to motivations, ESAI project 05116, Department of Sustainability and Environment and primary industries, Royal Melbourne Institute of Technology. Australia.

Takayama S, Bimston DN, Matsuzawa S, Freeman BC, Aime-Sempe C, Xie Z, Morimoto RJ and Reed JC (1997) Bag-1 modulates the chaperone activity of hsp70/hsc70. EMBO J 16: 4887-4896.

Zubair, A. O., 2006. Change detection in land use and Land cover using remote sensing data and GIS (A case study of Ilorin and its environs in Kwara State), M.sc Thesis, University of Ibadan, Nigeria. 